\title{
Making patents work: of IP duties and deficient disclosures
}

\author{
Shamnad Basheer* \\ Honorary Research Chair Professor of IP Law at Nirma University School of Law and the Founder \\ of SpicyIP
}

The Indian patent regime has been celebrated and censured in equal measure: celebrated by those that see in it the vestiges of a past, where nations could craft a patent policy to suit national priorities - without succumbing to the pressures of a global patent script and dictated largely by the industrial interests of the developed world-and censured by those who think that India's extensive use of TRIPS flexibilities to advance developmental priorities comes at the cost of global innovation incentives and a uniform patent paradigm.

Indeed, the present frame of the Indian patent regime contains a unique set of provisions not ordinarily found in other regimes. Patent working is one such provision. While most patent regimes demand 'disclosure', in that the patentee must elaborate the invention in full so as to educate the public and enable those skilled in the art to replicate it with relative ease, the Indian patent regime goes one step further. It requires that the disclosure even extend to the mode and manner in which patents are being worked for the greater public good. This information can then be used to trigger compulsory licences and even patent revocations. To this extent, the Indian patent regime not only grants exclusive IP rights, but also imposes a set of IP duties.

As an IP duty, patent working is central to the innovation ecosystem, for its disclosure helps foster greater transparency by inter alia pegging specific patents to products. This information is particularly valuable in the high technology sector, where it is often impossible to co-relate patents and the technological products that embody them, and vice versa. Unfortunately, Indian patentees routinely flout this important legal tenet, and the government has all but turned a blind eye to it.

This paper reflects on this important statutory mandate and its jurisprudential underpinnings, particularly in relation to two technology sectors: pharmaceuticals and high technology (IT and telecommunications). It highlights a writ petition filed by the author of this paper to showcase the sheer callousness with which the patent working requirement has been treated by both patentees and the government alike. It then discusses the ways in which the mandate could be strengthened so as to pave the way for a more meaningful patent regime and a more transparent innovation ecosystem.

Keywords: compulsory licensing, Indian Patents Act 1970, patents, public interest litigation

* This paper benefited from the insightful inputs of Sai Vinod, a Delhi-based lawyer who represents the author in a writ petition, from which some of the material for this piece has been drawn. This paper also benefited from excellent research assistance and inputs from Pankhuri Agarwal (Associate Editor, SpicyIP), Mathews George (Analyst, SpicyIP), Balaji Subramanium and Divij Joshi (both law students). My sincere gratitude to all of them, with the usual caveat that if they did mislead me into egregious errors, I am still to blame for not having cross checked. 


\section{INTRODUCTION}

A large part of the intellectual property narrative is a reductionist one, premised on the notion of a set of exclusive rights bestowed upon an inventor in order to spur innovation.

Unfortunately, this view does immense injustice to the larger vision of the patent system as one that seeks to strike a more holistic balance between the private monopoly rights of an inventor and the larger interests of the public. It is here that the notion of IP duties becomes important. For intellectual property is as much about the 'duties' owed by an IP owner to society as it is about the claim to exclusive rights. ${ }^{1}$ Illustratively, the Indian patent regime stipulates that if patent owners fail to satisfy the reasonable requirements of the public, the patented invention could be subject to a compulsory licence.

In order to monitor compliance with the above-mentioned duty, the Indian Patents Act, 1970 ('Indian Patents Act' or 'Patents Act') contains a rather unique provision, not found in most other regimes. It requires that every patent holder disclose the extent to which her patent has been commercialized and worked. Commonly labelled as 'patent working' disclosure, this statutory mandate has been a rather controversial one, with multinational corporations and the governments representing them advocating for its ouster. And yet this norm lies at the very heart of a patent system, in that it seeks to tether a twentyyear monopoly to the larger innovation ecosystem, and help demonstrate how the patented invention has translated to a useful innovation for society. Such a norm is particularly useful in technology sectors such as pharmaceuticals, IT and telecommunications.

This paper reflects on this important statutory requirement and the woefully inadequate manner in which it is currently implemented in India. To this end, it highlights a recent writ petition filed by the author showcasing the sheer callousness of patentees in complying with this important statutory mandate. It also takes issue with the flawed format currently deployed by the Indian Patent Office ('IPO') for drawing the requisite working information from patentees; and offers concrete suggestions for improving this.

\section{PATENT WORKING: THE RATIONALE?}

Patent working lies at the heart of a robust innovation eco-system, for, if patents are simply hoarded and deployed by those we now refer to as 'trolls' to extract excessive monopoly rents out of third party inventors (who tread only incidentally on patent toes), these twenty-year monopolies can have perilous effects on the innovation ecosystem. More importantly, an 'abusive' working of patents in the pharmaceutical sector (such as by charging excessive prices or not making a critical drug available to the patient population) can have deleterious public health consequences. Therefore, a requirement that the mode and manner in which a patent is being worked be disclosed to the general public is of prime importance to the innovation ecosystem, as outlined below.

\subsection{Intellectual property duties}

The grant of a patent represents a 'social bargain' between the state and the inventor, whereby an inventor who discloses new and valuable technological information to the

1. David Vaver, 'Intellectual Property: "Bargain” or Not?' (2012) 89 U. of Detroit Mercy L. Rev. 381, 388. 
public is rewarded with a state sanctioned monopoly for twenty (20) years. ${ }^{2}$ This bargain is best captured in the words of Justice Binnie (former judge of the Supreme Court of Canada): ${ }^{3}$

A patent, as has been said many times, is not intended as an accolade or civic award for ingenuity. It is a method by which inventive solutions to practical problems are coaxed into the public domain by the promise of a limited monopoly for a limited time. Disclosure is the quid pro quo for valuable proprietary rights to exclusivity ...

In the Indian context, the social bargain also comprises a promise that the patentee will work the patented invention for the public benefit, by ensuring that patented goods are generally accessible and affordable. ${ }^{4}$

In the event of this promise being breached, the statute provides for penalties in the form of a compulsory licence, or even a revocation of the patent. To this extent, the patent regime not only grants exclusive 'rights' to patentees to prevent others from manufacturing and distributing the patented invention, but also imposes 'duties' on them to work the invention for the public good.

For the most part, IP duties have been conceptualized from the standpoint of third parties who owe a duty to the IP owner to refrain from infringing the granted IP right. ${ }^{5}$

Unfortunately, few have framed IP duties from an IP owners' standpoint, that is, as a set of obligations imposed on the IP owner in order to effectuate the larger aims of any IP/innovation regime. One of the earliest to do so was Professor Drahos. While articulating a property-based paradigm for protecting the personhood of indigenous knowledge holders, Drahos proposed that the discourse around intellectual property hark back to an earlier era when it was seen as a mere privilege (as opposed to a property right), noting that such framing would then make this set of privileges more amenable to the imposition of definite 'duties':

... another reason for shifting intellectual property rights back to a discourse of privilege is that it helps to make clear the idea that intellectual property owners are the bearers of duties. ... If the purpose in creating the privilege is to fulfill some approved goal, then it should follow that the privilege holder is subject to duties not to exercise the privilege in a way that defeats the purpose for which the privilege was granted in the first place.

The Indian Patents Act exemplifies the spirit of the above sentiment ${ }^{7}$ through a number of provisions scattered through the written text of the law. Amongst other things, it

2. W Fisher, 'Theories of Intellectual Property' in SR Munzer (ed), New Essays in the Legal and Political Theory of Property (Cambridge University Press, Cambridge 2001), available at $<$ https://cyber.law.harvard.edu/people/tfisher/iptheory.pdf> 4, accessed 7 July 2016.

3. $\quad$ Apotex Inc. v Wellcome Foundation Ltd. [2002] 4 S.C.R. 153.

4. See discussion surrounding sections 83-85 of the Indian Patents Act 1970.

5. In many ways, this 'right:duty' jural correlative draws from Hohfeld's seminal structure. See WN Hohfeld, 'Fundamental Legal Conceptions as Applied in Judicial Reasoning' (1917) Faculty Scholarship Series. Paper 4378, <http://digitalcommons.law.yale.edu/cgi/viewcontent. cgi?article $=5383 \&$ context=fss_papers $>$ accessed 24 August 2016.

6. P Drahos, Indigenous Knowledge and the Duties of Intellectual Property Owners (1997) 11 Intellec. Prop. J. 179, 199.

7. For a similar sentiment in the context of copyrights, see David Vaver, 'Publishers and Copyright: Rights Without Duties?' (2006) 40(6) Bibliotheksdienst 743 who notes: 'Copyright should not just be about copyright owners' rights; it should also be about their duties. Historically, it used to be so: copyright owners used to owe duties to the public. Over time copyright law has been whittled down until it reads as if owners have just rights and no duties'. 
provides that patent owners have a definite duty to work the patent for the larger public benefit. This exhortation can be traced back to the Ayyangar Committee Report, ${ }^{8}$ a policy document that formed the blueprint for the 1970 patent regime, which noted:

Patents must be enabled to fulfill their prime purpose, viz., being worked in the country, and as early as possible after they are granted. Where this is incapable of being achieved, the law must enable a patent to be revoked.

Section 83 of the Patents Act, which in many ways constitutes the core essence of the public interest frame that underpins the Indian patent regime, endorses the Ayyangar Committee's sentiment in strong terms, stating:

(a) that patents are granted to encourage inventions and to secure that the inventions are worked in India on a commercial scale and to the fullest extent that is reasonably practicable without undue delay;

(b) that they are not granted merely to enable patentees to enjoy a monopoly for the importation of the patented article;

(c) that the protection and enforcement of patent rights contribute to the promotion of technological innovation and to the transfer and dissemination of technology, to the mutual advantage of producers and users of technological knowledge and in a manner conducive to social and economic welfare, and to a balance of rights and obligations;

(d) that patents granted do not impede protection of public health and nutrition and should act as instrument to promote public interest specially in sectors of vital importance for socio-economic and technological development of India;

(e) that patents granted do not in any way prohibit Central Government in taking measures to protect public health;

(f) that the patent right is not abused by the patentee or person deriving title or interest on patent from the patentee, and the patentee or a person deriving title or interest on patent from the patentee does not resort to practices which unreasonably restrain trade or adversely affect the international transfer of technology; and

(g) that patents are granted to make the benefit of the patented invention available at reasonably affordable prices to the public.

Chapter XVI of the Patents Act then goes on to translate the above guiding principles in more specific terms by providing for compulsory licences and revocations in select cases where the patent holder fails to satisfy the 'working' requirement, as explained below.

\subsection{Compulsory licensing and revocation}

Section 84 provides for the issuance of a compulsory licence in three broad situations, outlined below (provided three years have elapsed from the date of grant of the patent):

1. where the reasonable requirements of the public with respect to the patented invention have not been satisfied; or

2. where the patented invention is not available to the public at a reasonably affordable price; or

3. where the patented invention is not worked within the territory of India.

8. See N Rajagopala Ayyangar, Report on the Revision of the Patents Law (September 1959), II135; see also S Basheer, 'India's Tryst with TRIPS: The Patents (Amendment) Act, 2005' (2005) 1 Indian J. L. \& Tech. 15. 
If despite the issuance of the compulsory licence, the patent continues to remain unworked in India, it could be revoked any time after two years have elapsed from the date of grant of the compulsory licence. ${ }^{9}$

Section 84 was invoked for the first time in post-TRIPS India in a controversial dispute involving an expensive anti-cancer drug, Sorefanib Tosylate, sold as Nexavar by Bayer, a German multinational pharma firm.

Nexavar was sold at 2.8 lakhs INR a month and was available to only 2 per cent of the entire patient population in India. These facts were used by Natco, an Indian generic company, to request a compulsory licence from the IPO. Upon Natco's promise to sell the drug at 8,800 INR a month, the IPO granted a licence and mandated that Natco pay a 6 per cent royalty rate to the patentee. ${ }^{10}$

This decision of the IPO was then validated on almost all counts by the Intellectual Property Appellate Board ('IPAB') ${ }^{11}$ and the Bombay High Court. Interestingly, the Bombay High Court went to the extent of noting that even if a single patient did not have access to the drug, the reasonable requirements of the public could not be said to have been satisfied:

... it must be pointed out that Section 84(7) of the Act provides a deeming fiction which deems that reasonable requirement of the public is not satisfied, if the demand for patented article is not met to an adequate extent. The Parliament has deliberately used the word[s] 'adequate extent'. The aspect of adequate extent would vary from article to article. So far as luxury articles are concerned the meeting of adequate extent test would be completely different from the meeting of adequate extent test so far as medicines are concerned. In respect of medicines the adequate extent test has to be $100 \%$ i.e. to the fullest extent. Medicine has to be made available to every patient and this cannot be deprived/scarified at the altar of [the] rights of [the] patent holder. In fact this is the mandate of Parliament by providing for Compulsory Licensing.

While this threshold appears to be an extremely high one and renders almost all pharmaceutical patents susceptible to a compulsory licence, it is currently the law of the land. ${ }^{12}$

It bears noting that in its compulsory licensing application, Natco relied significantly on Bayer's patent working disclosures for Nexavar (in a format commonly referred to as 'Form 27') in order to demonstrate that:

1. Bayer was not able to satisfy the reasonable requirements of the public, in so far as access to its patented drug was concerned; ${ }^{13}$ and

2. The patent was not being 'worked' (manufactured) in India. ${ }^{14}$

9. See section 85 of the Indian Patents Act 1970.

10. Natco v Bayer, Compulsory License Application No. 1 of 2011, available at <http://www. ipindia.nic.in/iponew/compulsory_license_12032012.pdf> accessed 24 August 2016.

11. Bayer Corp. v Union of India and Ors., Order No. 45/2013, Mar. 4, 2013, IPAB. The IPAB differed on the issue of whether 'importing' a patented good would amount to 'working'. It also hiked up the royalty slightly to 7 per cent.

12. The Indian patent office is bound by rulings of the various high courts. See S Basheer, “"Policy Style" Reasoning at the Indian Patent Office' (2005) 3 I. P. Quarterly 309.

13. 'When one compares the demand with the working statement (Form-27) filed by the Patentee a clear picture of the demand not being met clearly emerges ...' Natco v Bayer, supra (n 10) at p. 13 .

14. 'A comparison of the working statement with the Patient base would clearly show that the Patent has not been worked in India', ibid at p. 37. 
The Controller General of Patents ('CG') agreed with most of these submissions and the underlying Form 27 data, as evident from the excerpts below:

1. 'In this regard, while considering the Application, the Form-27 filed by the Patentee was also considered by me. As per the Form-27 submitted by the Patentee, I found that in 2008 the Patentee did not import the drug at all, while in 2009 and 2010 the Patentee imported in small quantities. The quantities imported by the Patentee prima facie appeared to be grossly inadequate. ${ }^{, 15}$

2. 'It appears to me, from the Form-27 filed by the Patentee for the year 2009 and 2010, that only an insignificant quantum of the drug was made available by the Patentee to the public during these two years. ${ }^{16}$

3. 'In the instant case, the Patent was granted in the year 2008. It is an admitted fact that the Patentee does have the manufacturing facilities for manufacturing drugs in India, including Oncology drugs. However, even after the lapse of four years from the date of grant of patent, the Patentee failed to do so ... Accordingly, I hold that Section 84(1)(c) is attracted in this case and consequently a compulsory license be issued to the Applicant under Section 84 of the Act.' ${ }^{17}$

From the above, it is clear that the patent working data as found in the various Form 27 submissions is absolutely critical for triggering the compulsory licensing and revocation provisions.

\subsubsection{US/EU pressure}

Unfortunately, the grant of India's first post-TRIPS compulsory licence triggered the ire of a number of industry lobbies and their home governments, most notably the US and the EU. The Form 27 disclosure requirement also came under attack. Illustratively, the Intellectual Property Owners Association ('IPOA') noted in their submissions to the United States Trade Representative ('USTR'): ${ }^{18}$

Not only is this 'Form 27' process highly burdensome from an administrative point of view, but we are concerned that the information that is provided could be eventually used to justify compulsory licenses in a variety of industries, as specifically contemplated in the Form. Recently, submission of Form 27 has become publicly available, which is likely to result in even greater pressure on Indian authorities to compulsory license the covered products.

One might argue that this intense pressure brought to bear on India repeatedly by the US may have caused the government to be even more lax in their implementation of the patent working disclosure mandate. ${ }^{19}$

15. Supra (n 10) at p. 10.

16. Ibid at p. 22.

17. Ibid at p. 45 .

18. Submission of Intellectual Property Owners Association, Feb. 7, 2014, USTR-2013-0040, available at <http://www.regulations.gov/\#!documentDetail;D=USTR-2013-0040-0023> accessed 24 August 2016.

19. In 2014, for example, the US Trade Representative announced a Special 301 Outof-Cycle Review of India. See USTR Requests Public Comments for the 2014 Special 301 Out-of-Cycle Review of India, Office of the United States Trade Representative $<$ https://ustr.gov/federal-register-notices/USTR-Request-Public-Comments-2014-Special301-Out-of-Cycle-Review-India> accessed 1 October 2016; see also S Phurailatpam and 


\subsection{Patent working and injunctions}

Section 108(1) of the Patents Act encapsulates the various remedies available to a patentee in a suit for infringement, including an injunction and/or damages or accounts of profits. In awarding the said reliefs, section 109(1) requires the court to consider the loss suffered or likely to be suffered as a result of infringement. Patent working information as documented in the various Form 27 submissions is likely to play a crucial role in determining such 'loss'. Therefore, it is critical that this information be accurately and elaborately disclosed by all patentees.

Further, under the law as it stands now, a patentee who does not work her patented invention in India may not be able to restrain an alleged infringer. While refusing an injunction on this ground, the Delhi High Court in Franz Xaver Huemer v New Yash Engineering, ${ }^{20}$ noted:

For our purpose, the minority view pronounced by Douglas, J. in the Special Equipment Co. case is important. ... He said that a patent is not a form of private property but a 'privilege' 'conditioned by a public purpose,' to promote the progress of science and useful arts. (Mercoid Corp. v. Mid-Continent Invest Co., (1943) 320 US 661: 88 Law Ed 376). The exclusive right of the inventor is but the means to that end. This principle was recognised in several cases earlier in [the] US. But the Continental Paper Bag case had deviated radically from that theory and equated the 'exclusive' right with an 'absolute' right, thereby subordinating the public purpose of the grant to the self-interest of the patentee. The results were far reaching, observed Douglas, J.:

'The result is that suppression of patents has become common place. Patents are multiplied to protect an Economic barony or empire, not to put new discoveries to use for the common good.' ... We are in entire agreement with the strong views expressed by Douglas, J. in his dissenting judgment.

From the above, it is evident that the Indian patent law imposes strong intellectual property duties on IP owners in order that they might serve the interests of the public. A violation of these duties might result in three key sanctions:

1. Grant of a compulsory licence in accordance with Chapter XVI of the Patents Act;

2. Revocation of the patent in accordance with section 85; and

3. The denial of an injunction by courts of law.

\subsection{High technology, blocking patents and patent trolls}

Pharmaceutical patents are often critiqued for their engenderment of excessively high prices and consequent loss of consumer welfare. Prices are however a relative non-issue when it comes to other technology sectors, particularly electronics, IT and telecommunications (conveniently referred to as 'high technology'). ${ }^{21}$ The more

K Bhardwaj, 'The Pharmacy of the Developing World is Under Siege and it is Modi's Duty to Defend It' The Wire <http://thewire.in/2015/09/25/why-modi-must-defend-the-pharmacy-of-thedeveloping-world-11546/> accessed 25 September 2015.

20. Franz Xaver Huemer $v$ New Yash Engineering, ILR (1996) 2 Del 791.

21. High technology is commonly used to refer to 'scientific technology involving the production or use of advanced or sophisticated devices especially in the fields of electronics and computers', see 'High Technology', Merriam Webster <http://www.merriam-webster.com/ dictionary/high\%20technology> accessed 1 October 2016. 
egregious patent issues here revolve around blocking patents and patent 'trolls'. I argue that rigorous patent working and disclosure norms could curb some of these excesses, as elaborated upon below.

Blocking patents are not a precise term of art. ${ }^{22}$ Rather, they commonly refer to situations where a subsequent improvement patent over a prior patented technology cannot be commercialized without the permission of the prior patentee. In this way, an improved innovation, though patented, is potentially 'blocked' by the prior patent.

As with an earlier paper, ${ }^{23} \mathrm{I}$ argue that this term is rather limited and propose to use instead the term 'patent blocking' to include not only 'blocking patents', but also all instances where downstream research is blocked by patents on upstream inventions. In this way, I draw a distinction between the term 'blocking patents' (where there are two patents involved, one upstream and the other downstream) and 'patent blocking' (where one upstream patent blocks downstream innovation, whether that innovation is patented or not).

Patent blocking is not just a theoretical construct, but empirically shown to have played out in patent history. In a seminal piece, ${ }^{24}$ Merges and Nelson refer to broad patents covering technologies underlying Edison's light bulb, the Wright Brothers' airplane and Selden's automobile engine to buttress their claim that aggressive patent enforcement by patentees to ward off improvements ended up retarding technological progress. $^{25}$

Trolls could be said to engage in some form of patent blocking, by seeking to extract undue rents from those who attempt to build downstream innovations based on their upstream troll patent. Under India's patent regime, such potential blocking counts as an abusive working of the patent and could trigger compulsory licensing. But first, exactly who or what is a troll?

\subsubsection{Patent trolls}

A patent troll, also known as a patent assertion entity (PAE) or a non-practising entity (NPE), refers commonly to a patentee who is uninterested in working the patent by creating an innovative product or technology that will benefit the public. Rather such patentees hoard the patent in a bid to extract undue rents from legitimate third party inventors who happen to tread on the patents whilst developing one or more of their innovative products. ${ }^{26}$

22. For some general discussion on this term in the US context, see R Merges, 'Intellectual Property Rights and Bargaining Breakdown: The Case of Blocking Patents' (1994) 62 Tenn. L. Rev. 75, 81-2.

23. See S Basheer, 'Block Me Not: How “Essential” are Patented Genes?' (2005) 1 University of Illinois Journal of Law, Technology and Policy, available at $<\mathrm{http}: / / \mathrm{www}$.jltp.uiuc.edu/ archives/basheer.pdf> accessed 24 August 2016.

24. See RP Merges and RR Nelson, 'The Complex Economics of Patent Scope' (1990) 90 Colum. L. Rev. 840, 885-7, 890-91.

25. But see J Howells, 'Patents and Downstream Innovation Suppression - Facts or Fiction? A Critique of the Use of Historical Sources in Support of the Thesis that Broad Patent Scope Enables the Suppression or Hindrance of Downstream Useful-Technology Development' (2008), available at <http://www.pucsp.br/icim/ingles/downloads/pdf_proceedings_2008/11. pdf $>$ accessed 24 August 2016 (claiming that the treatment of these specific historical examples of blocking and the analysis by Merges \& Nelson on this count is not sound).

26. D McCurdy, 'Patent Trolls Erode the Foundation of the US Patent System' Science Progress, 12 January 2009; GN Magliocca, 'Blackberries and Barnyards: Patent Trolls and the Perils of Innovation’ (2007) 82 Notre Dame L. Rev. 1809, 1810. 
In other words, the sole purpose of a patent troll is to use the patent as a pure rent-seeking instrument. $^{27}$

However, the term 'patent troll' or 'patent assertion entity' is not without controversy. One might argue that there is nothing inherently wrong with deploying a patent for the sole purpose of extracting rents and with no personal desire to commercialize it. However, the problem arises when the royalty demanded is an excessively exorbitant one. Patentees who act reasonably whilst demanding royalties/licence fees for the use of their technology can hardly be said to harm the patent/innovation ecosystem, for it is not possible for all patentees to undertake product development themselves. Therefore, for the purpose of this piece, the term patent troll will be used only to denote those who engage in hold up and seek to extract unduly excessive rents from legitimate third party inventors or innovators.

The question of course arises as to whether or not one might be able to determine what is a reasonable licensing fee and what is not ${ }^{28}-$ a problem exacerbated and made uncertain by the fact that objective patent valuation is a myth and there are no standard measures for arriving at such objective value. ${ }^{29}$ A lot might therefore turn upon the conduct of the patentee. ${ }^{30}$

Aggressive patent assertion by trolls who demand unduly high licensing fees impairs the innovation ecosystem and creates market inefficiencies, thereby prejudicing public interest. ${ }^{31}$ This has prompted patent reform, particularly in the US. Illustratively, the Saving High-Tech Innovators from Egregious Legal Disputes Act of 2013

27. For a detailed discussion, see C Cotropia et al., 'Unpacking Patent Assertion Entities (PAEs)' (2014) 99 Minn. L. Rev. 649; see also M Lemley, 'Are Universities Patent Trolls?' (2008) 18 Fordham Intellec. Prop., Media \& Ent. L. J. 611.

28. See A Layne-Farrar and KM Schmidt, 'Licensing Complementary Patents: "Patent Trolls", Market Structure, and "Excessive" Royalties' (2010) 25 Berkeley Tech. L.J. 1121, available at <http://scholarship.law.berkeley.edu/btlj/vol25/iss2/7> accessed 24 August 2016 ('This term [patent troll] is used to describe a company that uses a patent to "hold-up" manufacturing companies to extort "excessive" royalties that are higher than the "fair share" dictated by the contribution of its patent. Unfortunately, it is notoriously difficult to determine whether royalties are excessive and to distinguish between aggressive (but legitimate) bargaining and hold-up').

29. M Perez Pugatch, 'What is the Value of Your Patent? Theory, Myth and Reality' (Draft), CiteSeerX, <http://citeseerx.ist.psu.edu/viewdoc/download?doi=10.1.1.565.2147\&rep=rep1\& type $=$ pdf $>$ accessed 24 August 2016 ('We also need to acknowledge that the value of a patent is ultimately subjective'); D Arsego, 'The Problem with FRAND: How the Licensing Commitments of Standard-Setting Organizations Result in the Misvaluing of Patents' (2015) 41 Brook. J. Int'l L. 257, 280 (2015), available at <http://brooklynworks.brooklaw.edu/cgi/viewcontent. cgi?article $=1416 \&$ context=bjil $>$ accessed 22 August 2016 ('Patent value as a whole is highly subjective').

30. See also MA Lemley and A Douglas Melamed, 'Missing the Forest for the Trolls' (2013) 113 Columbia L. Rev. 2117 ('Understanding the economics of patent assertions by both trolls and practicing entities allows us to move beyond labels ... and to focus instead on aspects of the patent system itself that give rise to the problems and on specific, objectionable conduct in which both trolls and practicing entities sometimes engage').

31. See C Cotropia et al., supra (n 27) ('There are numerous theories on the role of PAEs in the patent system. As mentioned in the introduction, many people (including President Obama's economic team) contend that PAEs "significantly retard innovation in the United States and result in economic 'dead weight loss' in the form of reduced innovation, income, and jobs for the American economy". They assert that PAEs hold up legitimate innovators by demanding undeserved rents'). 
('SHIELD Act') was considered in $2013 .{ }^{32}$ This bill sought to make trolls pay defendant and attorney costs in the event that they lost patent infringement suits. Unfortunately, it lapsed in the US Congress without being enacted..$^{33}$

It is interesting to note that while the US has historically been averse to the notion of statutorily prescribing compulsory patent working (with sanctions for non-working), ${ }^{34}$ some scholars are now beginning to seriously consider this, in the light of the troll phenomenon. ${ }^{35}$

Closer to home, in India, the classic troll story was played out by S Ramkumar who sought a patent over what is popularly called the 'dual sim' switching technology. After the patent was wrongly granted in 2008 (since the technology was already known as of the date of filing the patent application), ${ }^{36}$ Ramkumar deployed it to extort excessive sums of money from importers of dual SIM phones, ${ }^{37}$ including leading telecom companies such as Samsung, Mirc Electronics and Spice Mobile. ${ }^{38}$ He sought and obtained ex-parte injunctions to restrain them from manufacturing, importing and selling dual SIM handsets. ${ }^{39}$

32. H.R. 845, 113th Congress 2013-15, Introduced by Rep. Peter DeFazio on Feb. 27, 2013.

33. 'H.R. 845 (113th): Saving High-Tech Innovators from Egregious Legal Disputes Act of 2013', Status, govtrack.us, <https://www.govtrack.us/congress/bills/113/hr845> accessed 23 August 2016. See also J Bessen and BJ Love, 'Make the Patent "Polluters" Pay: Using Pigovian Fees to Curb Patent Abuse' (2013) The Circuit Paper 17, available at <http://scholarship.law. berkeley.edu/cgi/viewcontent.cgi?article=1016\&context=clrcircuit $>$ accessed August 242016 who document the other legislative efforts at curbing 'trolls'.

34. See A Mossoff, 'Exclusion and Exclusive Use in Patent Law' (2009) 22(2) Harvard J. L. \& Tech. 321, available at <http://jolt.law.harvard.edu/articles/pdf/v22/22HarvJLTech321.pdf> accessed 22 August 2016 ('By the late eighteenth century, courts had altered the quid pro quo of the patent from an affirmative duty to work the patented manufacture to a disclosure of the invention in the patent document. It was well established by 1790, the year in which Congress enacted the first Patent Act, that there was no legal requirement that a patentee work his invention. Similar to an owner of land, an American patentee was at liberty to do nothing with his invention but sue other people to prevent them from trespassing on his rights').

35. M Trimble, 'Patent Working Requirements: Historical and Comparative Perspectives' (2017 forthcoming) 6 U.C. Irvine L. Rev., UNLV William S Boyd School of Law Legal Studies Research Paper, available at <http://papers.ssrn.com/sol3/papers.cfm?abstract_id=2727624> accessed 8 July 2016.

36. Patent Application (Ref. 161/MAS/2002) filed on March 4, 2002, titled 'Mobile phone with a plurality of simcards allocated to different communication networks' ('Dual SIM switching technology'). The patent converted to a grant (Patent No. IN214388) on 11 February 2008. See CH Unnikrishnan, 'Dual SIM Dispute Highlights Flaws in India's Patent Process', Mint, 20 July 2009, available at <http://www.livemint.com/Companies/64vk1wINDEaDtxkj1KpuJK/Dual-SIMdispute-highlights-flaws-in-India8217s-patent-pr.html> accessed 24 August 2016; S Basheer, 'Customs Seizures in India: Patently Unconstitutional?', SpicyIP, 13 March 2009, <http://spicyip. com/2009/03/customs-seizures-in-india-patently.html> accessed 24 August 2016.

37. S Basheer, 'Ramkumar vs Cell Importers: India's Biggest IP Case Yet?', SpicyIP, 9 August $2009<\mathrm{http}: / /$ spicyip.com/2009/08/ramkumar-vs-cell-importers-indias.html> accessed 24 August 2016.

38. S Basheer, 'The Growing Promiscuity of Indian Courts in Granting "Ex Parte" Injunctions', SpicyIP, 24 March 2009) <http://spicyip.com/2009/03/growing-promiscuity-of-indiancourts-in.html> accessed 24 August 2016.

39. Ex parte injunctions were obtained, for instance, against Samsung and Spice. S Dama, 'Interrogating Interim Injunctions: Ramkumar's Dual-SIM Patent', SpicyIP, 23 June 2015, $<$ http://spicyip.com/2015/06/interrogating-interim-injunctions-ramkumars-dual-sim-patent. html> accessed 24 August 2016. 
The patent was finally revoked by the IPAB on 1 June 2012, since it was neither new nor inventive. ${ }^{40}$ However, by this time, a number of technology companies had paid out huge sums of money in what can only be described as one of the most egregious patent plunders. It is pertinent to note that the patent specification did not even offer any indication of how the proposed new technology might actually work. It was clear that the sole aim of registering the patent was to extort money from technology companies who happened to deploy the patent in one or more of their products.

Here again, the compulsory licensing mechanism within the Indian Patents Act offers some scope for redressing wanton patent abuses of the kind engaged in by Ramkumar. Assuming the Ramkumar patent was indeed a valid one (complying with the patentability criteria of novelty, inventive step, utility and enabling disclosure), interested third parties could have applied for a compulsory licence on the ground that the patentee had failed in his duty and not worked the patent in the territory of India (even after three years from the date of patent grant). ${ }^{41}$ In this way, third party innovators could have avoided the kind of hold-up that trolls typically subject them to. This is where Indian patent law strikes a rather different chord from other regimes such as the US regime where there is no statutory entitlement to a compulsory licence in the event of a non-working troll attempting to extract undue rents from the system.

However, in order to effectuate such a compulsory licensing provision, a full and complete disclosure of working information under Form 27 is critical, for it tells the public whether or not the patentee has worked or intends to work the patent or has merely registered it in order to extract excessive rents, as a troll does. This level of transparency is absolutely critical to calling out trolls and ensuring there are no serious patent bumps on the innovation superhighway. Indeed, patent working promotes transparency within the innovation ecosystem, as elucidated below.

\subsection{Transparency and the patent: product linkage}

Another significant advantage of the patent working requirement is in fostering greater transparency in the innovation ecosystem. In particular, it does this by forcing the patentee to disclose the patent-product nexus, that is, the various products/technology that use the granted patent in some way and vice versa.

Unfortunately, the patent system today has been gamed to facilitate a trade secrecy of sorts. Patentees have been known to hide more than they reveal in a patent specification, thereby blunting the disclosure requirement. Courts have come down hard on patentees that do so, but only in the few instances where matters have reached them. Illustratively, the Canadian Supreme Court struck down Pfizer's patent for Viagra (Sildenafil Citrate) on the ground that the use of 'Sildenafil Citrate', as an enabler of erections, was not sufficiently disclosed in the patent, castigating Pfizer's patent strategy:

Pfizer gained a benefit from the Act - exclusive monopoly rights - while withholding dis-

closure in spite of its disclosure obligations under the Act. As a matter of policy and

40. P Reddy, 'IPAB Revokes Patents Belonging to Debutant Indian "Patent Trolls", SpicyIP, 5 July 2012, <http://spicyip.com/2012/07/ipab-revokes-patents-belonging-to.html> accessed 24 August 2016. See R Sivaraman, 'Intellectual Property Board Revokes Patent for Dual SIM Phones', The Hindu, 10 June 2012.

41. See section 84(1)(c) and earlier discussion on section 84, supra part 2.2. 
sound statutory interpretation, patentees cannot be allowed to 'game' the system in this way. ${ }^{42}$

Similarly, patentees have been known to keep the patent-product nexus a secret, particularly in the pharmaceutical and high technology areas. ${ }^{43}$ The working disclosure requirement breaks this problematic opacity, forcing patentees to disclose the various patents in their embedded products or technology.

To this extent, the working requirement might also help us critically evaluate the link between patents and inducement of innovation, a link that has, as yet, not been credibly established. As a scholar notes: ${ }^{4}$ 'Despite the economic logic of the conventional view, there exists surprisingly little empirical evidence to support the key assumption that patents do actually spur technological innovation'. Commentators point to the existence of various non-IP incentives such as branding, lead-time and trade secrecy, ${ }^{45}$ casting doubt on the notion that intellectual property rights necessarily enhance the rate and range of innovations across all technology sectors. ${ }^{46}$ Illustratively, Levin et al. found that the firms they surveyed did not consider patents as very important for protecting the competitive advantage stemming from their innovations. $^{47}$

42. Teva Canada Ltd. v Pfizer Canada Inc. [2012] 3 S.C.R. 625; S Basheer, 'Sex, Side Effects and a Vague Viagra Patent: IP Jurisprurience?', SpicyIP, 8 July 2016, <http://spicyip.com/2016/ 07/ip-juris-prurience-sex-side-effects-and-a-vague-viagra-patent.html $>$ accessed 24 August 2016.

43. See generally R Cooper Feldman, 'Transparency' (2015) Virginia J. L. \& Tech. (2015), available at $<\mathrm{http}: / /$ repository.uchastings.edu/cgi/viewcontent.cgi? article $=2049 \&$ context $=$ faculty_scholarship> accessed 22 August 2016; see also United Nations Development Programme (UNDP), 'Patent Information and Transparency: A Methodology for Patent Searches on Essential Medicines in Developing Countries' (July 2012), available at <http://www.undp.org/ content/undp/en/home/librarypage/hiv-aids/a-methodology-for-patent-searches-on-essentialmedicines-in-deve.html> accessed 22 August 2016 at p. 9 ('Despite long-standing concerns over the implications of patent protection on access to medicines, there is still considerable uncertainty regarding the existence of patents on particular medicines because there are often difficulties in obtaining such patent information, particularly in the developing countries. Furthermore, patent information on pharmaceutical products is often not easily accessible or available in an easily understood form').

44. A Torrance and B Tomlinson, 'Patents and the Regress of Useful Arts' (2009) 10 Columbia Sci. Tech. L. Rev. 132 (2009); see also Committee on Intellectual Property Rights in the Knowledge Based Economy, Nat'l Research Council of the Nat'l Acads., A Patent System for the 21st Century 81-130 (SA Merrill et al. eds, 2004), available at <http://www.nap. edu/catalog.php?record_id=10976> accessed 24 August 2016 ('[t]here are theoretical as well as empirical reasons to question whether patent rights advance innovation in a substantial way in most industries').

45. A Arora et al., 'R\&D and the Patent Premium' (2008) 26 Int'l. J. of Ind'l. Org. 1153; see also WM Cohen et al., 'Protecting Their Intellectual Assets: Appropriability Conditions and Why U.S. Manufacturing Firms Patent Or Not' (2000) NBER Working Paper 7552.

46. See WM Cohen and H Sauermann, 'Schumpeter's Prophecy and Individual Incentives as a Driver of Innovation' in F Malerba and S Brusoni (eds), Perspectives on Innovation (Cambridge University Press, Cambridge 2007) 73-104; see also B Hall, 'Patents and Patent Policy' (2007) 23(4) Oxford Review of Economic Policy 568, 574.

47. RC Levin et al., 'Appropriating the Returns from Industrial Research and Development' (1987) 18(3) Brookings Papers on Economic Activity 783. Similar results have been obtained by Cohen, Nelson and Walsh who conducted a similar survey in the US (Cohen et al., supra (n 45)). 
Edwin Mansfield, in an early empirical study of firms' patenting behaviour, discovered that patents are not a significant incentive for driving innovation in most sectors:

In primary metals, electrical equipment, instruments, office equipment, motor vehicles, rubber, and textiles, very few additional inventions were commercially introduced because of patent protection, according to the firms themselves. (In many of these industries, patent protection was reported to have not been essential for the introduction of any of their inventions during this period.) However, in a few industries, particularly pharmaceuticals and chemicals, the effects of the patent system were reported to be very substantial. ${ }^{48}$

Even in so far as pharmaceutical technologies are concerned, the author has argued in the past that the patent system is sub-optimal and should therefore give way to a more optimal investment protection regime. ${ }^{49}$

\section{PATENT WORKING AND TRIPS COMPLIANCE}

Indian patent law makes clear that any failure to work a patent could trigger compulsory licensing and even patent revocation in certain cases. However, the term 'working' has not been defined in the Patents Act and there is a raging controversy around whether or not it includes 'imports' of the patented invention into India.

In the famed Nexavar case (Bayer $v$ Natco) discussed earlier in this paper, the IPO categorically held that mere imports could not be said to constitute 'patent working'. Relying on sections 83(b) and 83(c) of the Indian Patents Act, it held that working must necessarily mean local working or local manufacture. ${ }^{50}$ This would ensure that the patentee 'contribute towards the transfer and dissemination of technology'. ${ }^{51}$

However, on appeal, the IPAB disagreed with this view, holding that imports could, in certain circumstances, constitute 'working' and that this would have to be determined on a case-by-case basis. In its words:

[W] find that the word worked must be decided on a case to case basis and it may be proved in a given case, that working can be done only by way of import, but that cannot apply to all other cases. The patentee must show why it could not be locally manufactured. A mere statement to that effect is not sufficient there must be evidence. ${ }^{52}$

In other words, imports could be considered to amount to working, provided the patentee is able to demonstrate why the invention could not be locally manufactured, and had to necessarily be imported. ${ }^{53}$

48. E Mansfield, 'Patents and Innovation: An Empirical Study' (1986) 32(2) Management Science $173,180$.

49. S Basheer, 'The Invention of an Investment Incentive for Pharmaceutical Innovation' (2012) 15 Journal of World Intellectual Property 305.

50. 'Section 83(b) states that Patents are not granted merely to enable patentees to enjoy a monopoly for importation of the patented article. Upon a reading of this provision it becomes amply clear to me that mere importation cannot amount to working of the patented invention', Natco v Bayer, supra (n 10) at p. 43.

51. Natco v Bayer, supra (n 10) at p. 43.

52. Bayer Corp. and Anr. v Union of India and Ors., supra (n 11) II 52.

53. 'Working ... in some cases could mean only importation. It would depend on the facts and evidence of each case', ibid. 
Unfortunately, the IPAB ruling does not really tell us what those circumstances are when an 'import' could be said to constitute patent working. More importantly, this finding of the IPAB flies in the face of section 83, which makes it amply clear that patents cannot be granted for the mere purpose of importation. ${ }^{54}$

\subsection{TRIPS compatibility}

There is considerable debate around whether or not a local working requirement is TRIPS compliant. Some argue that it contravenes the Article 27 mandate to desist from discriminating between patented inventions that are locally produced and those that are imported. However, a close reading of Article 27 and an appreciation of its interpretative contours from WTO rulings which categorically held that discrimination is only 'unjustified' differentiation, would make clear that a local working provision is defensible under the terms of Article 27.

In pertinent part, Article 27 reads: 'patents shall be available and patent rights enjoyable without discrimination as to the place of invention, the field of technology and whether products are imported or locally produced'. The WTO panel in the Canada - Patent Protection of Pharmaceutical Products case held that a distinction ought to be drawn between discrimination and differential treatment, with the former being a subset of the latter. For something to amount to a discrimination, it must entail an 'unjustified imposition of differentially disadvantageous treatment' ${ }^{55}$ In other words, this is to be assessed on a case-by-case basis, taking into account the context and whether or not the differentiation could be legitimately justified. ${ }^{56}$

In a developing country context, one could easily argue that a local working provision could potentially trigger technology transfer and is therefore justifiable. ${ }^{57}$ This 'technology transfer' rationale is made amply clear in the Ayyangar Committee Report, which drew significantly from European patent history to advocate for a strong local working provision. Specifically, it recounted the history of the UK, which introduced local working provisions to curb expensive patented imports from Germany. ${ }^{58}$

It was hoped that a local working provision (forcing the patentee to manufacture in the UK or license a domestic entity to so produce) would generate local employment, promote technology transfer and keep the prices of patented goods low. ${ }^{59} \mathrm{In}$ fact, the

54. Section 83(b), Indian Patents Act 1970.

55. Panel Report, Canada - Patent Protection of Pharmaceutical Products, II7.94, WT/ DS114/R (Mar. 17, 2000).

56. BC Mercurio and M Tyagi, 'Treaty Interpretation in WTO Dispute Settlement: The Outstanding Question of the Legality of Local Working Requirements' (2011) 19 Minnesota Journal of International Law 275, 294.

57. See Trimble, supra (n 35) at p. 23 (' $\ldots$ transfers [of technology] will occur only if patented inventions are actually manufactured inside the country; importation alone will do little if anything to bring about any technology or know-how transfers').

58. See Ayyangar, supra (n 8) at p. 27; see also Trimble, supra (n 35) at p. 25 ('It was concern about the development of the domestic chemical industry in the United Kingdom that led at the beginning of the 20th century to the tightening of the patent working requirement in the United Kingdom at a time it was felt by the U.K. government that German companies had begun to monopolize the U.K. chemical industry').

59. The British debates around the introduction of a local working provision in the 1902 and 1907 Acts and also the Swan Committee Report of 1949, stressed the need to encourage the transfer of technology across national boundaries, so as to develop self-sufficiency in strategic industrial sectors such as chemicals and pharmaceuticals. See Ayyangar, supra (n 8) at pp. 49-61. 
UK provisions were so stringent that they effectively provided that even if the patentee did not 'mainly' work the patent in the UK, the patent could be revoked. ${ }^{60}$ These provisions were however subsequently deleted or diluted, and under current UK law there can be no revocation of a patent for non-working. Even as far as the remedy of compulsory licensing for non-working is concerned, only patents of entities belonging to non-WTO countries can be penalized through such a remedy. ${ }^{61}$

The Ayyangar Committee Report drew on this wisdom and recommended a similar provision for India in the hope that this would induce patentees to voluntarily license their inventions, which could in turn promote technology transfer. ${ }^{62}$

Lastly, a close reading of the Paris Convention suggests the defensibility of a local working provision within the broad contours of TRIPS. Article 5A(1) of the Paris Convention provides that an importation of patented articles by the patentee shall not entail a forfeiture of patent. ${ }^{63}$ This could be taken to suggest that importation could entail something less than forfeiture, such as compulsory licensing. This conclusion is buttressed by the fact that Article $5 \mathrm{~A}(2)$ goes on to state that each member shall have the right to provide compulsory licences in order to prevent any abuse of patent rights, including a 'failure to work the patent'. Article 5A(4) then provides that such compulsory licences cannot be granted if the patentee could submit legitimate reasons to justify the fact that he was not able to locally work the patent.

This line of reasoning was first mentioned in a research report co-authored by the author and was later picked up by the CG in the Nexavar ruling. ${ }^{64}$

\section{PATENTEE COMPLIANCE WITH WORKING DISCLOSURE}

As evident from the above discussion, patent working constitutes a central pillar of the Indian patent regime. In order to assess the existence and extent of working, the regime contains extensive provisions calling for regular disclosure of working information. Despite this strong mandate, patentees routinely fail to submit patent working information, as recounted below - but first, a survey of the statutory framework and provisions governing the working disclosure mandate.

60. The Patents \& Designs Act 1907, section 27(1) ('At any time not less than four years after the date of a patent, and not less than one year after the passing of this Act, any person may apply to the comptroller for the revocation of the patent on the ground that the patented article or process is manufactured or carried on exclusively or mainly outside the UK').

61. The Patents Act 1977, section $48 \mathrm{r} / \mathrm{w}$ section $48 \mathrm{~B}$ (1) ('In the case of an application made under section 48 above in respect of a patent whose proprietor is not a WTO proprietor, the relevant grounds are - (a) where the patented invention is capable of being commercially worked in the United Kingdom, that it is not being so worked or is not being so worked to the fullest extent that is reasonably practicable ...').

62. Ayyangar, supra (n 8) at p. 61, I140 ('If the possibility of the grant of a compulsory licence acts as an inducement to the grant of a voluntary licence on reasonable terms, it stands to reason that this inducement or pressure must be greater if the grounds on which the licence could be granted were enlarged, or if otherwise the obtaining of the licence were made easier by suitable modification of the adjectival law').

63. Article $5 \mathrm{~A}(1)$ states that 'Importation by the patentee into the country where the patent has been granted of articles manufactured in any of the countries of the Union shall not entail forfeiture of the patent'.

64. See S Basheer and M Kochupillai, "The "Compulsory Licence" Regime in India: Past, Present and Future', Report for the Japanese Patent Office (2005). Natco v Bayer, supra (n 10) at p. 41. 
Under Section 146(1) of the Patents Act, the CG can direct any patentee or licensee to supply patent working information at any time. Section 146(2) then goes on to stipulate that notwithstanding the power above, patentees and their licensees have to mandatorily submit periodic statements on patent working. ${ }^{65}$

The mandate under section 146(2) was elaborated upon in a rule promulgated by the government (Rule 131) to oblige every patentee to disclose working information as per the format specified in Form 27. This form requires patentees and their licensees to disclose the following particulars:

1. whether the patented invention has been worked on a commercial scale within India for the year in question;

2. if the patented invention is not worked, the reasons for such non-working;

3. if the patented invention is worked, the rights holder must:

(a) specify the quantum and value of the manufacture of the product covered by the patent in India as well as importation from other countries for the relevant year;

(b) specify the details of licences and sub-licences granted during the relevant year;

(c) state whether the patented invention is manufactured within the territory of India in the relevant year; and

(d) state whether the public requirement of the patented invention has been met either partly or adequately or to the fullest extent at a reasonable price for the relevant year.

Any non-compliance with the above disclosure requirement triggers a fine which could extend up to 1 million INR. ${ }^{66}$ Unfortunately, despite these sanctions, a large number of patentees routinely flout this important statutory mandate, as highlighted below. ${ }^{67}$

\subsection{Non-compliance}

In a survey undertaken by the author and his research associates, ${ }^{68}$ a large number of patentees (almost 35\%) failed to disclose any working information at all between the years 2009 and 2012. ${ }^{69}$ While a vast majority did not bother stating any reasons for their failure to disclose, others proffered what can only be described as suspect reasons. Illustratively, high technology major Ericsson claimed that their patents were being worked through licensing arrangements but refused to disclose these on the

65. Such information can then be published by the CG under section 146(3).

66. See section 122(1)(b) of the Indian Patents Act, 1970 which authorizes the CG to impose such fines.

67. Written Submissions on behalf of the Petitioner, Shamnad Basheer v Union of India, WP (C) 5590/2015, Delhi High Court, <http://spicyip.com/wp-content/uploads/2015/05/FORM-27WP-1R-copy.pdf $>$ accessed 24 August 2016, IIII22-25 ['Written Submissions']; see also Annexure P-11.

68. This survey did not cover all patents registered in India but only those within three select categories: pharmaceutical drugs, telecommunications, and those that emanated from publicly funded research and development.

69. Written Submissions, at p. 9; see also Annexure P-7. 
grounds of "confidentiality'; ${ }^{70}$ meanwhile Motorola Mobility contended that working information was impossible to furnish due to the nature of their inventions. ${ }^{71}$

\subsection{Deficient compliance}

Apart from the blatant non-compliance showcased above, a significant number of patentees submitted information that was deficient in important particulars, that is, grossly incomplete, incomprehensible or inaccurate, as detailed below:

1. Only 17 of the 85 Form 27 submissions in the telecom sector (from amongst those that we surveyed) disclosed the quantity/value of sales. ${ }^{72}$

2. A mere 31 disclosures mentioned any sort of licensing arrangement, ${ }^{73}$ a statistic that is particularly problematic given the prevalence of large-scale patent licensing in the high technology sector.

3 . Form 27 requires every patentee to mention the quantity of the patented product, either manufactured or imported. A vast majority of the Form 27 filings that we surveyed (close to $60 \%$ approximately) provided the import or sales figures in vague or indeterminate units of measurement, thereby preventing a fair assessment of patent working. Illustratively, the Form 27 filed in 2009-10 for Bayer's controversial drug Nexavar ${ }^{\circledR}$ (Patent No. IN21578) states that while 4665 units of the drug were imported into India, only 1679 units of the drug were sold. Unfortunately, the form does not tell us the actual number of tablets contained in each of 4665/1679 units. Nor does it mention the number of such units required by each patient per month. ${ }^{74}$ Without these figures, it is well-nigh impossible to determine whether or not Bayer could be said to have satisfied the reasonable requirements of the cancer patient population that needed its drug.

4. Among those patentees that disclosed the value of their sales in India, many did not bother to specify the rate of conversion while using foreign currency figures. ${ }^{75}$

5. In cases where the patent has not been worked, Form 27 requires patentees to provide reasons for non-working and detail the measures being taken to redress it. Twenty-eight out of 42 filings that we surveyed did not bother outlining any reasons for failure to work. ${ }^{76}$

6. Form 27 requires each patentee to indicate whether or not the reasonable requirement of the public has been met, either partly, adequately or to the fullest extent, at a reasonable price. A vast majority of Form 27 filings simply stated that the reasonable requirements have been met, without offering any data or explanation in support of this.

70. Ibid I[23; see also Annexure P-8.

71. Ibid $\llbracket[23$.

72. Ibid Annexure P-11. Also only one Form 27 submission disclosed the place of manufacture.

73. Ibid Annexure P-11.

74. Ibid at p. 13; see also Annexure P-9. A copy of this filing can be found at $<\mathrm{http}: / / \mathrm{www}$. spicyip.com/docs/Form\%2027s.pdf> accessed 24 August 2016.

75. Ibid at p. 15.

76. Ibid Annexure P-12. 
7. While three pharmaceutical patentees claimed that they met the reasonable requirements of the public through various Patient Assistance Programs ('PAPs'), they failed to disclose the specific extent of assistance provided to patients. Illustratively, the Form 27 declaration filed in 2011 for Bayer's Nexa$\operatorname{var}^{\circledR}$ claimed that the reasonable requirements of the public had been meet to the fullest extent. However, in the compulsory licensing dispute outlined earlier, it was found (by the IPO and later the IPAB and the Mumbai High Court) ${ }^{77}$ that Bayer could hardly be said to have satisfied the reasonable requirements of the public, given that its drug was far too expensive and a mere 2 per cent of the patient population had access to it.

8. Despite the clear inclusion of licensees within the working disclosure framework, the IPO reported that, as of March 2014, no Form 27 had been received from licensees. In response to an RTI query, the IPO went as far as to indicate that there was no legal duty upon licensees to furnish patent working information. ${ }^{78}$ Further, even in a highly controversial compulsory licensing dispute that garnered global attention, the IPO failed to monitor Natco's compliance with the Form 27 requirement as a licensee of Bayer's patented Nexavar, albeit a compulsory licensee (if one can use that term). It bears noting that while issuing the licence, the IPO imposed several conditions on Natco, including a specific obligation to account for the sales of the licensed patented drug on a quarterly basis. However, Natco does not appear to have complied with this condition and disclosed this data. ${ }^{79}$

The above findings are neither surprising nor new. In an earlier survey conducted by the author along with his research associates and covering some of the leading multinational pharmaceutical firms, similar egregious instances of non-compliance were found. ${ }^{80}$

Illustratively, one of the firms surveyed (Schering) reported in its Form 27 filing that it was importing the drug Viraferonpeg, but did not provide any further details of the quantum of imports or sales within India. Instead, it merely stated that 'Information not readily available. Information will be provided if asked for' ${ }^{81}$

Other instances of deficient compliance by others included multiple inconsistent Form $27 \mathrm{~s}$ filed for the same product in a year, and a woeful failure to state any reasons whatsoever for non-working. ${ }^{82}$

77. This finding has attained finality, with the Hon'ble Supreme Court of India upholding the grant of compulsory licence by the IPO vide order dated December 12, 2012 in SLP(C) No. 30145 of 2014. Ibid at p. 14; see also Annexure P-10.

78. See RTI application filed by Sai Vinod, Counsel for the Author in Writ Petition, Written Submissions, Annexure P-12.

79. Written Submissions, at p. 18; see also Annexure P-15. While the government mentioned in its reply to the writ that such data had been filed, it is nowhere to be found on the patent office website or in any of the documents pertaining to the Bayer patent.

80. S Basheer and S Vinod, "Report on RTI Applications and "Working" of Foreign Drugs in India?', SpicyIP (Apr. 2011), available at <http://spicyip.com/2011/04/drug-firms-and-patentworking-extent-of.html> accessed 24 August 2016; see also S Basheer and R Samuel, 'Bayer's Nexavar and the "Working" of Compulsory Licensing: Mind the Patent (Information) Gap!', SpicyIP, April 2015, <http://spicyip.com/wp-content/uploads/2015/04/Report-on-Bayer-forwrit-Finalized.pdf $>$ accessed 24 August 2016.

81. Basheer and Vinod, ibid at p. 8.

82. Ibid at p. 9. 
Given this history, ${ }^{83}$ it is clear that the government and the IPO have committed a gross dereliction of public duty by failing to act against errant patentees.

One might argue that the rather nebulous frame of Form 27 facilitates this strategic non-disclosure by patentees. The writ petition filed by the author devotes an entire section to this issue and outlines some suggestions to improve the current format of Form 27. However, rather than casting any of these recommendations specifically in stone, the petition asks that a committee be constituted to suggest more optimal measures in this regard. ${ }^{84}$

\section{REFORMING FORM 27}

The current version of Form 27 is far from satisfactory, suffers from a large amount of ambiguity, and omits to ask patentees for a number of important particulars. These are discussed in seriatim below:

1. Form 27 merely asks patentees and licensees to 'give whatever details are available'. Owing to this nebulous wording, patentees and licensees have strategically provided rather vague and non-specific information that makes it impossible to determine the extent of working.

2. Paragraph 3(i)(b) of the current Form 27 states:

If worked: quantum and value (in Rupees), of the patented product:

(a) manufactured in India,

(b) imported from other countries (give country wise details).

By merely querying the quantum of manufacture, and not the numbers that are ultimately sold in India or even the 'value' of such sales, the present format is insufficient to assess the extent to which the patented invention is able to meet the reasonable requirements of the public. This information played a critical role in the Nexavar compulsory licensing dispute. Both the IPO and the appellate authorities (IPAB and Mumbai High Court) found it challenging to determine the total number of patients receiving Bayer's patented drug (when compared with the overall number of patients requiring the drug). This had to be taken from Bayer's submissions in court, and could not be accurately determined from its various Form 27 submissions, which were incomplete and vague in several particulars. ${ }^{85}$

3. Paragraph 3(ii)(b) of the current Form 27 requires patentees to disclose the licensing information in very general terms: 'give whatever details are available: the licences and sub-licences granted during the year'.

83. See e.g., R Mukherjee, 'Drug MNCs Violating Patent Law?', The Times of India, 7 April 2011, available at <http://timesofindia.indiatimes.com/business/india-business/Drug-MNCsviolating-patent-law/articleshow/7890728.cms> accessed 24 August 2016; CH Unnikrishnan, 'Drug Firms May Have Breached Patent Norms', Mint, 6 April 2011, available at <http://www. livemint.com/Companies/3acEyhjvhRhPOTAMiiQBtO/Drug-firms-may-have-breached-patentnorms.html> accessed 24 August 2016.

84. Written Submissions, at p. 41 ('WHEREFORE the Petitioner respectfully pray that this Hon'ble Court may, in public interest, be pleased to: ... (4) To constitute a committee of experts to suggest reforms to improve the public disclosure norms around the commercial working of patents').

85. Basheer and Samuel, supra (n 80). 
Due to this lack of emphatic specificity, a number of Form 27 submissions simply fail to disclose the details of licensees or licensing arrangements. In order to make for a more effective assessment, Form 27 must clearly ask whether the patent has been licensed in the first place. If so, more elaborate details must be called for, such as the names of licensees, the broad terms of the licence, whether products are being manufactured under the licence, whether such licences are exclusive or not, etc. This requirement may not pose an onerous obligation, as patentees are already known to internally capture this information for accounting and other commercial and tax purposes.

4. The Form 27 declaration merely requires patentees to state whether or not the reasonable requirements of the public have been met through their invention. However, this is too vague, nebulous and absurd a question, as it is difficult to imagine any patentee forthrightly declaring that they have not met the requirements of the public. Not too surprisingly, none of the patentees who formed part of our survey were vacuous enough to make this candid admission.

The author's writ petition proposed that rather than relying on patentees to self-attest satisfactory patent working, the Form 27 format ought to demand more information, such as would make for a more objective assessment. In particular, each patentee ought to be made to submit the following details:

(a) estimated demand for the patented invention or product; and

(b) the extent to which the said demand has been met, through sales and PAPs, etc.

5. While a couple of patentees refer to their PAPs as evidence of 'working', none of them provide any details as to the precise extent of such assistance provided to patients. This makes it difficult to determine whether or not reasonable requirements have been met through the PAPs.

6. When it comes to high technology patents, it is often the case that a single basic patent can be embedded in multiple products, technologies and improvements. Conversely, a single product could have multiple patents embedded within it.

Given the sheer importance of fostering more transparency within the high technology sector, as discussed earlier, ${ }^{86}$ Form 27 ought to be amended to explicitly call for this information. Specifically, the patentee must be made to disclose all technologies, applications and products, which to the patentees' knowledge contain the patent. Similarly, patentees must furnish a complete list of patents and patent applications covering a particular technological product that they make/sell/disburse, either directly or through licensees. Illustratively, if Siemens is the originator of CDMA technology and has secured protection for it through various patents, ${ }^{87}$ it ought to disclose all of these patents in each of its Form 27 filings. Similarly, if it directly licenses these patents to various implementers of technology and is collecting royalties from them, it must also disclose each of these technologies/products where its patent has found a commercial translation.

86. See supra part 2.4.

87. 'CDMA or Code Division Multiple Access is a digital wireless technology that converts analog information, such as speech, into digital information, which is then transmitted as a radio signal over a wireless network. CDMA uses spread-spectrum technology, decreasing potential interference while achieving privacy. CDMA technology is the basis for third generation $(3 \mathrm{G})$ wireless technologies which offer increased voice capacity and provide higher data rates than $2 \mathrm{G}$ and $2.5 \mathrm{G}$ networks', definition provided by CDMA Development Group, available at $<$ http://www.cdg.org/resources/acronyms.asp > accessed 24 August 2016. 
While this seems complicated, it could be implemented in a relatively easy manner by simply requiring that Siemens disclose all 'related' or 'associated' patents for each product that it discloses in each Form 27 filing. In other words, every patentee that holds multiple patents covering a single product must disclose other 'related' patents in their Form 27 for each such patent.

\subsection{Problematic online format}

It bears noting that apart from the physical format for Form 27 that patentees routinely submit, the IPO also provides an online submission option. ${ }^{88}$ The online version is however even more problematic than the offline format, requiring even less specificity in the information to be provided by patentees. Illustratively, patentees and licensees are not required to submit information pertaining to the quantum of the patented product imported or manufactured as part of the online form. Even if they wish to do so, the online form is such that they are effectively prevented from entering this information. ${ }^{89}$ This blatant dilution of an important statutory mandate enables patentees and their licensees to evade public scrutiny of the true extent to which the patent has been licensed and worked.

\subsection{Government response}

In their response to the writ petition, the government did not contest in strong terms any of the allegations mounted in the petition including the fact that they failed to take action against errant patentees. However, they noted that since the date of filing of the writ petition, they have released a draft amendment of the patent rules for public comments; ${ }^{90}$ these rules included a revised format for Form $27 .{ }^{91}$

Since then, these draft rules were finalized and came into force on May 16, 2016. ${ }^{92}$

While the reformed Form 27 in the amended rules represents a slightly better version of the earlier form, ${ }^{93}$ it does not go far enough. Although it does away with the ridiculous self-attestation prospect by the patentee as to "whether reasonable public requirements have been met partially, sufficiently or adequately?', it does not use the opportunity to solicit more specific information from the patentee in order to objectively make this assessment, such as:

1. the estimated demand for the patented invention or product; and

2. the extent to which the said demand has been met.

88. The IPO introduced 'Comprehensive Online Filing Services for Patents' ('e-filing facility') in 2012 to provide a convenient way for patentees and licensees to file various forms online, including Form 27.

89. Written Submissions 28; see also Annexure P-13.

90. The Patent (Amendment) Rules, 2015 (Draft), available at <http://www.ipindia.nic.in/ IPActs_Rules/PatentRules_2015_E_29October2015.pdf> accessed 24 August 2016.

91. Ibid section 30(vii) at p. 38 .

92. The Patent (Amendment) Rules, 2016, available at <http://ipindia.nic.in/IPActs_Rules/ Patent_(Amendment)Rules_2016_16May2016.pdf> (accessed 24 August 2016).

93. The new form does away with the vaguely worded leeway provided to patentees earlier to: 'give whatever details available'. It also compels all licensees to state the nature of the patent licence (ie exclusive or otherwise). 
The form also retains some of the vague phrases and terms from earlier. Patentees and licensees are required to provide the 'value' of the patented product, but it is not clear what is meant by 'value' of the patented invention. Illustratively, would it mean value in terms of actual 'sales' of the patented invention in India?

Surprisingly, this draft amendment to the Form 27 was never finalized and the new set of rules that came into force did not include this new format. ${ }^{94}$

The response also suggests that all Form $27 \mathrm{~s}$ filed by patentees are available online. However, while this is true in that the relevant patent entry on the IPO website may contain the relevant Form 27 as well, there is no updated consolidated database of Form 27s that have been filed. The IPO did release such a database in earlier years, but only for Form 27s submitted in certain years (calendar years 2012 and 2013 only). As a result, the Form 27 filings pertaining to the years 2003 to 2011, 2014 and 2015 are not conveniently available for public viewing through a single web page/interface. Rather, one has to go through each individual patent entry to determine whether or not Form 27s have been filed and updated for that particular patent.

In order to provide for better transparency, it is critical that the government immediately put up all working information (as encapsulated in the various Form 27s) in one consolidated page on their website. ${ }^{95}$

\section{CONCLUSION}

Patent disclosure lies at the very heart of the patent bargain. However, while disclosing the full details of a patented invention (so as to educate the public and enable those skilled in the art to replicate it with relative ease) is important, working the patent for the greater public good is equally important. To this extent, this is an important IP duty that merits strong recognition in each regime.

The Indian Patents Act recognizes this important duty and mandates in strong terms that patentees work their patents and disclose details of working on a timely basis. Unfortunately, patentees all but ignore this important statutory safeguard. Further, the IPO has made a mockery of this mandate through their overly lax oversight. It is hoped that the court before which a writ petition outlining this statutory dereliction has been filed (by the author of this piece) will force the government to enforce this mandate in stricter terms.

Further, as this paper has shown, the current format of Form 27 is insufficient to achieve the objects sought to be achieved by the Patents Act, namely that of generating meaningful information on patent working. Any deficit in this information is likely to not only harm the public notice function that patents serve but also detrimentally impact the prospect of compulsory licensing and revocation in appropriate cases where the patentee fails to live up to their part of the patent bargain. The paper therefore makes some recommendations for a more optimal working disclosure format.

The Indian experience is a rich and unique one, and will be of some value to other countries that desire more out of the patent system than merely granting a set of exclusive rights. Indeed, patent working and disclosure is central to fostering a more transparent innovation ecosystem; one that helps us understand the patent-product nexus better, and determine whether patents ultimately work for overall societal benefit.

94. The Patent (Amendment) Rules, 2016, supra (n 92).

95. See also rejoinder to the government reply, which makes this point. 